\title{
PENGGUNAAN MODEL PEMBELAJARAN KOOPERATIF TERPADU MEMBACA DAN MENULIS UNTUK MENINGKATKAN KETERAMPILAN MENULIS BERITA SISWA KELAS VIII A SMPN 2 LABUAN AMAS UTARA KABUPATEN HULU SUNGAI TENGAH
}

\author{
Irni Cahyani dan Heppy Lismayanti
}

\section{Pendidikan Bahasa dan Sastra Indonesia STKIP PGRI Banjarmasin}

Jalan Sultan Adam, Komplek H. Iyus, No. 18 RT.23 Banjarmasin,

Kalimantan Selatan. Kode pos 70121

email: irnicahyani@ stkipbjm.ac.id

\begin{abstract}
ABSTRAK
Latar belakang penelitian adalah rendahnya nilai siswa dalam menulis berita karenakurangnyaminat bacasiswa dan guru menggunakan teknik yang tradisional dalam pembelajaran dikelas, seperti berceramah didepan kelas lalu memberikan tugas. Tujuan penelitian adalah mendeskripsikan peningkatan keterampilan menulis berita, memaparkan aktivitas guru dansiswa, mengungkapkan respons siswakelas VIII A SMPN 2 Labuan Amas Utara dalam pembelajaran menulis berita melalui penggunaan model pembelajaran kooperatif terpadu membaca dan menulis. Manfaat penelitian adalah meningkatkan keterampilan menulis berita, meningkatkan kualitas pembelajaran, dan masukan bagi sekolah dalam meningkatkan kualitas pembelajaran di sekolah, sehingga guru-guru dapat melakukan penelitian bila menemukan permasalahan dalam pembelajaran.

Jenis penelitian yang dilaksanakan adalah Penelitian Tindakan Kelas yaitu penelitian tindakan yang dilakukan oleh guru sekaligus sebagai peneliti di kelasnya atau bersama dengan guru dengan jalan merancang, melaksanakan, dan merefleksikan tindakan secara kolaboratif dan partisipatif yang bertujuan untuk memperbaiki atau meningkatkan keterampilan menulis berita. Penelitian ini dilaksanakan dalam pembelajaran menulis berita pada siswa kelas VIII A SMPN 2 Labuan Amas Utara Kabupaten Hulu Sungai Tengah.

Berdasarkan hasil penelitian diperoleh simpulan sebagai berikut: (1) Setelah proses pembelajaran bahasa Indonesia materi menulis berita dengan penerapan model pembelajaran Kooperatif Terpadu Membaca dan Menulis siklus II pertemuan ke-2 selesai dilaksanakan, diketahui hasil belajar siswa menunjukkan peningkatan ketuntasan belajar siswa, baik secara individual maupun klasikal. Pada siklus I diperoleh nilai rata-rata siswa 74,75 dengan ketuntasan belajar individu sebanyak 12 orang dan ketuntasan belajar klasikal 60\%. Setelah siklus II selesai dilaksanakan, maka terlihat peningkatan hasil belajar siswa sebesar 35\% dengan nilai rata-rata siswa di atas indikator keberhasilan yaitu 75, dengan ketuntasan belajar individu sebanyak 19 orang dan ketuntasan belajar klasikal 95\%. (2) Tahapan-tahapan pembelajaran berlangsung efektif karena tidak ada lagi kegiatan yang belum terlaksana dari proses belajar mengajar yang berjalan lancar dan mendapat respons yang baik dari siswa. Hal ini dapat dibuktikan dari keaktifan siswa dalam mengikuti proses pembelajaran. (3) Pembelajaran Bahasa Indonesia di kelas VIII A SMP Negeri 2 Labuan Amas Utara dengan materi menulis berita dengan menerapkan model pembelajaran Kooperatif Terpadu Membaca dan Menulis mendapat respons yang positif dari siswa, meskipun model pembelajaran Kooperatif Terpadu Membaca dan Menulis ini masih dianggap hal yang baru bagi para siswa, tetapi dengan adanya inovasi tersebutlah, siswa menjadi bersemangat dalam belajarnya di kelas, serta juga dapat meningkatkan hasil belajar keterampilan menulis berita.
\end{abstract}

Kata Kunci: kooperatif terpadu, membaca menulis, berita 


\section{PENDAHULUAN}

Kegiatan pembelajaran bahasa Indonesia dimaksudkan untuk melatih membaca, berbicara, mendengarkan, mengapresiasi karya sastra/menyimak dan menulis.Tujuanpembelajaran bahasa dan sastra Indonesia adalah melatih meningkatkan kemampuan berbahasa Indonesia, baik lisan maupun tulisan secara nyata. Dari tujuan pembelajaran terlihat bahwa kegiatan menulis adalah salah satu kegiatan yang sangat berperan penting dalam pembelajaran bahasa Indonesia. Salah satu keterampilan menulis yang diajarkan pada mata pelajaran Bahasa Indonesia kelas VIII SMP adalah menulis berita. Berdasarkan hasil wawancara dengan Ibu Sri Hartati (guru Bahasa Indonesia SMP Negeri 2 Labuan Amas Utara) salah satu cara yang dapat dilakukan guru yaitu dengan memberikan materi yang bersifat nyata atau yang pernah dialami siswa, sehingga dapat menimbulkan imajinasi siswa dan menjadikan materi tersebut menjadi mudah diserap oleh siswa dan dapat meningkatkan hasil belajar mereka. Namun, masih ada siswa yang kurang paham materi yang dijelaskan, serta sulit dalam mengembangkan materi berdasarkan pada pengalaman siswa.

Berdasarkan hasil observasi yang dilakukan di SMP Negeri 2 Labuan Amas Utara, kemampuan siswa kelas VIII A SMP Negeri 2 Labuan Amas Utara dalam menulis berita masih rendah. Kondisi tersebut disebabkan berbagai hal termasuk di dalamnya minat baca siswa terhadap berita dan penggunaan model pembelajaran yang kurang disenangi siswa atau pembelajaran masih tergantung dengan informasi dari guru, terlihat dari hasil kemampuan siswa dalam menulis berita masih belum mencapai hasil yang sesuai dengan KKM padapelajaran Bahasa Indonesia yang sudah ditetapkan oleh guru. Bila diberikan evaluasi hasil belajar menulis berita masih rendah.

Penyebab utama rendahnya nilai siswa dalam menulis berita ini bukan hanya disebabkan karena kurangnya minat bacasiswa, tetapi juga sampai saat ini masih banyak guru yang menggunakan teknik yang tradisional dalam pembelajaran dikelas, antara lain guru berceramah didepan kelas, lalu memberikan tugas. Belum adanya model pembelajaran yang digunakan dalam pembelajaran Bahasa Indonesia membuat pembelajaran ini serasa monoton, sehingga siswa kurang aktif dalam mengikuti pelajaran. Oleh karena itu,peneliti tertarik untuk menggunakan model pembelajaran kooperatif terpadu membaca dan menulis,agarpembelajaran yang dilaksanakan dapat menarik minat baca siswa, yang pada akhirnya meningkatkan hasil belajar siswa.

Ketikasiswabelajar dengan aktif, berarti mereka yang mendominasi aktivitas pembelajaran. Dengan ini, mereka secara aktif menggunakanotak kanan, baik untuk menemukan ide pokok dari materi, memecahkan persoalan atau mengaplikasikan apa saja yang mereka pelajari kedalam suatu persoalan, yang ada dalam kehidupannyata. Hal ini sesuai dengan pendapat yang dikemukakan oleh Faidi (2013:45) bahwa belahan otak kananmerupakan sumber intuisi, insight, kiasan dan imajinasi.Dikemukakan bahwa otak kanan memiliki potensi yang begitu besar dalam hal 
mendorong seseorang untuk menjadi pribadi yang kreatif dan kaya akan ide-ide baru. Dengan kerja otak kanan yang maksimal, sama halnya dengan mencipta diri menjadi manusia yang kreatif dan berguna, baik bagi diri sendiri maupun orang lain.Terkait permasalahan yang terjadi di SMP Negeri 2 Labuan Amas Utara apabila dibiarkan, maka hasil belajar siswa berada di bawah standar yang ditetapkan, dan perlu diremedial oleh guru bahasa Indonesia. Sehubungan dengan hal tersebut, maka perlu diadakan perbaikan kualitas pembelajaran, sebagai jalan keluar, agar kemampuan siswa dalam menulis berita meningkat. Berdasarkan latar belakang masalah yang dikemukakan di atas, peneliti terdorong untuk melakukan penelitian,agar permasalahan dalam pembelajaran Bahasa Indonesia dapat diatasi. Judul penelitian yang akan dilaksanakan adalah: "Penggunaan model pembelajaran Kooperatif Terpadu Membaca dan Menulis untuk Meningkatkan Keterampilan Menulis Berita pada Siswa Kelas VIII A SMP Negeri 2 Labuan Amas Utara Kabupaten Hulu Sungai Tengah".

\section{METODE}

Penelitian Tindakan Kelas merupakan suatu pencermatan terhadap kegiatan belajar berupa sebuah tindakan, yang sengaja dimunculkan dan terjadi dalam sebuah kelas secara bersama (Arikunto, dkk. 2012: 3). Penelitian Tindakan Kelas ini adalah penelitian yang dilakukan oleh guru di dalam kelasnya sendiri melalui refleksi diri, dengan tujuan untuk memperbaiki kinerjanya, sehingga hasil belajar siswa menjadi meningkat (Wardani, dkk. 2007: 1.4). Penelitian Tindakan Kelas ini direncanakan berlangsung dalam 2 siklus, setiap siklus terdiri dari beberapa tahap, yaitu: (1) perencanaan, (2) tindakan, (3) observasi atau pengamatan, dan (4) refleksi, seperti uraian berikut.

\section{Tindakan Siklus I}

\section{a. Perencanaan (Planning)}

Sebelum dilaksanakan penelitian, perlu diadakan berbagai persiapan sehingga semua komponen yang direncanakan dapat dikelola dengan baik. Langkah-langkah persiapan yang akan ditempuh pada tahap perencanaan adalah sebagai berikut.

1. Membuat silabus

2. Membuat Rencana Pelaksanaan Pembelajaran.

3. Mempersiapkan contoh berita.

4. Mempersiapkan Lembar Kegiatan Siswa (LKS).

5. Membuat lembar observasi aktivitas siswa dan guru.

6. Membuat tes keterampilan menulis berita. 


\section{b. Tindakan (Action)}

Pelaksanaan tindakan untuk perbaikan merupakan kegiatan inti dalam siklus Penelitian Tindakan Kelas. Penelitian ini dilaksanakan selama 2 siklus. Setiap pertemuan 2 x 40 menit (2 jam pelajaran). Siklus II dilaksanakan, bila diperlukan perbaikan hasil dan proses pembelajaran siklus 1. Kegiatan pembelajaran dilaksanakan mengikuti skenario penelitian berikut.

1. Skenario Pembelajaran Siklus I Pertemuan 1 ( 2 x pertemuan)

Kegiatan awal:

a) Guru mempersiapkan siswa (doa dan absen)

b) Melakukan apersepsi dan motivasi.

c) Guru menyampaikan orientasi materi.

d) Guru menyampaikan tujuan pembelajaran.

e) Guru melaksanakan test awal (pretest).

Kegiatan inti:

1) Guru menyajikan materi tentang menulis berita sebagai pengantar.

2) Guru mengelompokkan siswa menjadi beberapa kelompok secara heterogen.

3) Guru memerintahkan siswa agar bekerja sama antar kelompok.

4) Perwakilan dari kelompok menyampaikan hasil kerja kelompok masing-masing.

Kegiatan akhir:

1) Guru membimbing siswa membuat kesimpulan.

2) Guru bersama siswa melakukan refleksi

3) Guru memberikan tes akhir membaca berita (posttest).

2. Skenario Pembelajaran Siklus I Pertemuan 2

Kegiatan awal:

a) Guru mempersiapkan siswa secara apersepsi.

b) Guru menyampaikan orientasi materi.

c) Guru memotivasi siswa.

d) Guru menyampaikan tujuan pembelajaran.

Kegiatan inti:

a) Guru menyajikan materi tentang menulis berita secara garis besar sebagai pengantar.

b) Guru mengelompokkan siswa secara heterogen.

c) Guru memerintahkan siswa agar bekerja sama antar kelompok.

d) Perwakilan dari kelompok menyampaikan hasil kerja kelompok masing-masing.

e) Guru memerintahkan siswa agar bekerja sama antar kelompok.

f) Siswa memberikan tanggapan atas kerja kelompoknya. 
Kagiatan akhir:

a) Guru membimbing siswa membuat kesimpulan.

b) Guru bersama siswa melakukan refleksi

c) Guru memberikan tes akhir membaca berita (posttest).

\section{c. Pengamatan (Observation)}

Observasi dilakukan untuk memperoleh data partisipasi, aktivitas siswa, dan berbagai gejala ketika pembelajaran berlangsung. Observasi juga digunakan untuk mendapatkan data aktivitas siswa dan aktivitas guru dalam pembelajaran menulis berita, untuk melihat keterampilan siswa dalam menulis berita.

\section{d. Refleksi (Reflection)}

Refleksi dilakukan setelah data pembelajaran diolah, atau setelah guru mempunyai gambaran tentang keberhasilan/kegagalan atau kekuatan/kelemahan tindakan perbaikan yang dilakukan. Kekuatan ingatan dan kejujuran dalam melakukan refleksi sangat membantu guru menemukan kekuatan dan kelemahan tindakan perbaikan yang telah dilakukan, sehingga dapat dihasilkan masukan yang bermakna bagi perencanaan daur berikutnya (Wardani, dkk. 2007: 4.43).

\section{Tindakan Siklus II}

\section{1) Perencanaan}

Sebelum dilaksanakan penelitian, perlu diadakan berbagai persiapan sehingga semua komponen yang direncanakan dapat dikelola dengan baik. Langkah-langkah persiapan dilakukan seperti pada siklus I, peneliti menyusun rencana sebagai berikut.

1. menyusun Rencana Pelaksanaan Pembelajaran (RPP)

2. menyususn instrument pembelajaran

3. menyusun lembar observasi

4. menyusun jadwal pelaksanaan penelitian

\section{2) Pelaksanaan}

Pelaksanaan tindakan untuk perbaikan merupakan kegiatan inti dalam siklus Penelitian Tindakan Kelas. Penelitian sebanyakdua kali pertemuan dan setiap pertemuan terdiri dari 2 jam pelajaran. Siklus IIini dilaksanakan untuk perbaikan hasil dan proses pembelajaran pada siklus I. Kegiatan pembelajaran dilaksanakan dengan mengikuti skenario berikut.

1) Skenario Pembelajaran Siklus IIPertemuan 1 ( 2 x pertemuan)

Kegiatan awal:

a) Guru mempersiapkan siswa secara apersepsi.

b) Guru menyampaikan orientasi materi. 
c) Guru memotivasi siswa.

d) Guru menyampaikan tujuan pembelajaran.

Kegiatan inti:

a) Guru menyajikan materi tentang menulis berita secara garis besar sebagai pengantar.

b) Guru mengelompokkan siswa secara heterogen.

c) Guru memerintahkan siswa agar bekerja sama antar kelompok.

d) Perwakilan dari kelompok menyampaikan hasil kerja kelompok masing-masing.

e) Guru memerintahkan siswa agar bekerja sama antar kelompok.

f) Siswa memberikan tanggapan atas kerja kelompoknya.

Kagiatan akhir:

a) Guru membimbing siswa membuat kesimpulan.

b) Guru bersama siswa melakukan refleksi

c) Guru memberikan tes akhir membaca berita (posttest).

3. Skenario Pembelajaran Siklus I Pertemuan 2

Kegiatan awal:

a) Guru mempersiapkan siswa secara apersepsi.

b) Guru menyampaikan orientasi materi.

c) Guru memotivasi siswa.

d) Guru menyampaikan tujuan pembelajaran.

Kegiatan inti:

g) Guru menyajikan materi tentang menulis berita secara garis besar sebagai pengantar.

h) Guru mengelompokkan siswa secara heterogen.

i) Guru memerintahkan siswa agar bekerja sama antar kelompok.

j) Perwakilan dari kelompok menyampaikan hasil kerja kelompok masing-masing.

k) Guru memerintahkan siswa agar bekerja sama antar kelompok.

1) Siswa memberikan tanggapan atas kerja kelompoknya.

Kagiatan akhir:

d) Guru membimbing siswa membuat kesimpulan.

e) Guru bersama siswa melakukan refleksi

f) Guru memberikan tes akhir membaca berita (posttest).

\section{3) Observasi}

Observasi dan evaluasi dilaksanakan dengan melakukan pengamatan pada siswa dalam kegiatan pembelajaran bahasa Indonesia materi menulis berita. Kegiatan evaluasi dilakukan melalui pemberian tes untuk mengetahui peningkatan keterampilan siswa kelas VIII A SMP negeri 2 Labuan Amas Utara Kabupaten Hulu Sungai Tengah dalam menulis 
berita. Dari hasil kegiatan observasi, peneliti mengetahui tindakan yang harus dilakukan dalam penelitian.

\section{4) Refleksi}

Refleksi siklus I diadakan dengan cara mendiskusikan antara guru kelas VIII dengan peneliti tentang kekurangan yang perlu diperbaiki selama proses pembelajaran. Apabila indikator keberhasilan belum tercapai pada siklus I, maka dilanjutkan pada siklus berikutnya. Langkah-langkah Penelitian Tindakan Kelas tersebut dapat dilihat pada gambar berikut ini.

\section{Alur Penelitian Tindakan Kelas}

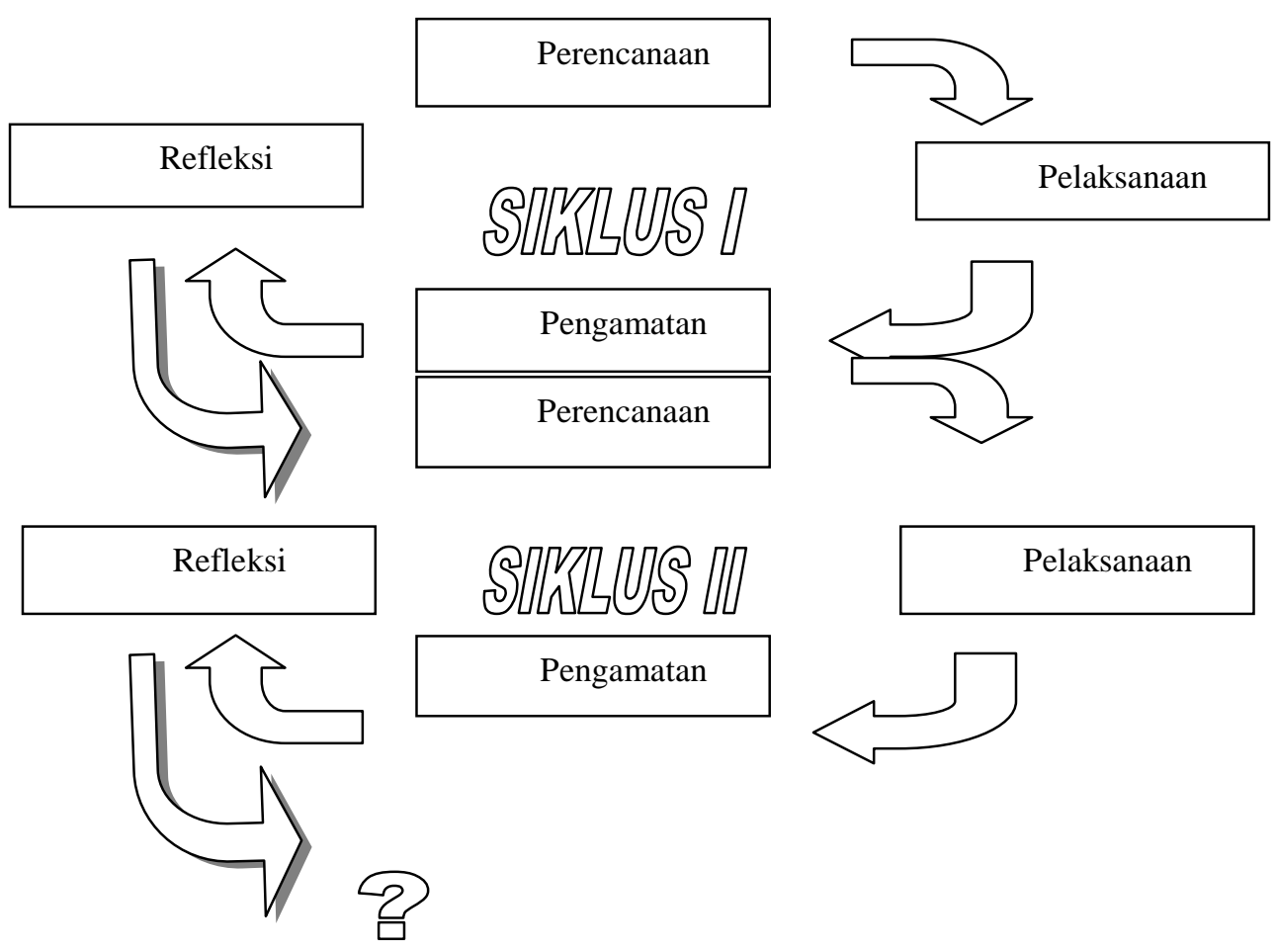

Gambar 3.1 Alur Penelitian Tindakan Kelas menurut Arikunto (2012:16)

\section{HASIL DAN PEMBAHASAN}

Siklus I terdiri dari dua kali pertemuan, seluruh aktivitas guru dalam pembelajaran menulis berita meliputi perencanaan, pelaksanaan, observasi, dan refleksi, seluruh rangkaian kegiatan tersebut dapat dilihat pada uraian berikut ini.

\section{Perencanaan Tindakan}

Berdasarkan Rencana Pelaksanaan Pembelajaran yang dibuat, maka skenario pembelajaran pada siklus I dapat dijelaskan berikut ini.

1. Skenario Pembelajaran Siklus I Pertemuan 1 ( 2 x pertemuan) 
Kegiatan awal:

1. Guru mempersiapkan siswa (doa dan absen).

2. Melakukan apersepsi dan motivasi.

3. Guru menyampaikan orientasi materi.

4. Guru menyampaikan tujuan pembelajaran.

5. Guru melaksanakan test awal (pretest).

Kegiatan inti:

1. Guru menyajikan materi tentang menulis berita sebagai pengantar.

2. Guru mengelompokkan siswa menjadi beberapa kelompok secara heterogen.

3. Guru memerintahkan siswa agar bekerja sama antar kelompok.

4. Perwakilan dari kelompok menyampaikan hasil kerja kelompok masing-masing.

Kegiatan akhir:

1. Guru membimbing siswa membuat kesimpulan.

2. Guru bersama siswa melakukan refleksi

3. Guru memberikan tes akhir membaca berita (posttest).

2. Skenario Pembelajaran Siklus I Pertemuan 2

Kegiatan awal:

1. Guru mempersiapkan siswa kemudian memberikan apersepsi .

2. Guru menyampaikan orientasi materi.

3. Guru memotivasi siswa.

4. Guru menyampaikan tujuan pembelajaran.

Kegiatan inti:

1. Guru menyajikan materi tentang menulis berita secara garis besar sebagai pengantar.

2. Guru mengelompokkan siswa secara heterogen.

3. Guru memerintahkan siswa agar bekerja sama antar kelompok.

4. Perwakilan dari kelompok menyampaikan hasil kerja kelompok masing-masing.

5. Guru memerintahkan siswa agar bekerja sama antar kelompok.

6. Siswa memberikan tanggapan atas kerja kelompoknya.

Kagiatan akhir:

1. Guru membimbing siswa membuat kesimpulan.

2. Guru bersama siswa melakukan refleksi

3. Guru memberikan tes akhir membaca berita (posttest).

Semua rencana pembelajaran akan dilaksanakan pada tindakan pembelajaran. 


\section{Pelaksanaan Tindakan}

Pertemuan pertama pembelajaran menulis berita dilaksanakan pada hari Selasa, 25 April 2018,pada siswa kelas VIII A SMP Negeri 2 Labuan Amas Utara dengan materi menulis berita. Kegiatan pembelajaran yang dilaksanakan guru pada siklus I pertemuan pertama dapat dilihat berikut ini.

Aktivitas guru pada kegiatan awal adalah mempersiapkan siswa kemudian memberikan apersepsi. Guru menyampaikan orientasi materi. Guru memotivasi siswa. Guru menyampaikan tujuan pembelajaran.

Aktivitas guru pada kegiatan inti adalah guru menyajikan materi pelajaran tentang menulis berita secara garis besar sebagai pengantar.Guru mengelompokkan siswa secara heterogen.Guru memerintahkan siswa agar bekerja sama antar kelompok.Perwakilan dari kelompok menyampaikan hasil kerja kelompok masing-masing.Guru memerintahkan siswa agar bekerja sama antar kelompok.Siswa memberikan tanggapan atas kerja kelompoknya.

Aktivitas guru pada kagiatan akhir adalah guru membimbing siswa membuat kesimpulan.Guru bersama siswa melakukan refleksi dan guru memberikan tes akhir membaca berita (posttest).

\section{Observasi}

Data hasil penelitian ini diambil melalui pengamatan peneliti bersama kolaborator menggunakan instrumen penelitian proses dengan dan hasil pembelajaran. Instrumen penilaian proses terdiri dari dua jenis, yaitu diperuntukkan untuk guru dan siswa. Data hasil pembelajaran siswa disediakan belajar. Penelitian ini telah dilaksanakan melalui dua siklus, dimana setiap siklusnya terdiri dari dua tahap dengan jadwal penelitian sebagai berikut.

Tabel 4.1

Jadwal Penelitian

\begin{tabular}{|l|l|l|l|}
\hline No. & Siklus & \multicolumn{1}{|c|}{ Pertemuan } & \multicolumn{1}{|c|}{ Hari/ Tanggal } \\
\hline 1. & Siklus I & Pertemuan ke-1 & Rabu, 25 April 2018 \\
& & Pertemuan ke-2 & Sabtu, 28 April 2018 \\
\hline 2. & Siklus II & Pertemuan ke-1 & Rabu, 2Mei 2018 \\
& & Pertemuan ke-2 & Sabtu, 5Mei 2018 \\
\hline
\end{tabular}

\section{a. Hasil Prasiklus}

Hasil prasiklus keterampilan menulis berita sebelum dilakukan tindakan penelitian dilakukan dengan tujuan untuk mengetahui keadaan awal kemampuan menulis berita pada siswa kelas VIII A SMP Negeri 2 Labuan Amas Utara. Tahap prasiklus ini dilaksanakan pada Selasa, 24 April 2018. Hasil tes prasiklus keterampilan menulis berita dapat dilihat pada tabel 4.2 berikut. 
Tabel 4.2

Hasil Belajar Keterampilan Menulis Berita Tahap Prasiklus

\begin{tabular}{|c|c|c|c|}
\hline No. & Nama & Nilai & Kriteria Keberhasilan \\
\hline 1. & Abdul Hakim & 75 & Tuntas \\
\hline 2. & Ahmad Jarkasi & 60 & Tidak Tuntas \\
\hline 3. & Ahmad Sayuti & 75 & Tuntas \\
\hline 4. & Amrullah & 70 & Tidak Tuntas \\
\hline 5. & Haris Fadillah & 70 & Tidak Tuntas \\
\hline 6. & Ida Rahma & 65 & Tidak Tuntas \\
\hline 7. & Kamarudin & 55 & Tidak Tuntas \\
\hline 8. & Karina & 80 & Tuntas \\
\hline 9. & Khairunnisa & 75 & Tuntas \\
\hline 10. & Muhammad Eko & 75 & Tuntas \\
\hline 11. & Muhammad Faisal & 65 & Tidak Tuntas \\
\hline 12. & Muhammad Ibnu & 65 & Tidak Tuntas \\
\hline 13. & Muhammad Izuddin & 55 & Tidak Tuntas \\
\hline 14. & Muhammad Jaini & 55 & Tidak Tuntas \\
\hline 15. & Muhammad Rifani & 70 & Tidak Tuntas \\
\hline 16. & Norlisa & 65 & Tidak Tuntas \\
\hline 17. & Radiah & 75 & Tuntas \\
\hline 18. & Riska Hidayati & 75 & Tuntas \\
\hline 19. & Sahrani & 75 & Tuntas \\
\hline 20. & Saniyah & 75 & Tuntas \\
\hline \multicolumn{2}{|c|}{ Jumlah Nilai } & 1375 & \\
\hline \multicolumn{2}{|c|}{ Rata-rata } & 68,75 & \\
\hline \multicolumn{2}{|c|}{ Jumlah siswa tuntas (9 orang) } & $45 \%$ & \\
\hline
\end{tabular}

Dari tabel 4.2 tentang hasil belajar pada tahap prasiklus dengan materi menulis berita digambarkan belajar hasil belajar siswa pada tabel 4.3 berikut.

Tabel 4.3

Predikat Hasil Belajar Tahap Prasiklus

\begin{tabular}{|c|c|c|c|c|}
\hline Nilai & Frekuensi & $\boldsymbol{\%}$ & $\begin{array}{c}\text { Predikat } \\
\text { Prestasi }\end{array}$ & $\begin{array}{c}\text { Kriteria } \\
\text { Keberhasilan }\end{array}$ \\
\hline 55 & 3 & 15 & Kurang & Tidak Tuntas \\
\hline 60 & 1 & 5 & Kurang & Tidak Tuntas \\
\hline 65 & 4 & 20 & Kurang & Tidak Tuntas \\
\hline 70 & 3 & 15 & Kurang & Tidak Tuntas \\
\hline 75 & 8 & 40 & Cukup & Tuntas \\
\hline 80 & 1 & 5 & Baik & Tuntas \\
\hline Total & 20 & 100 & & \\
\hline
\end{tabular}

Berdasarkan tabel 4.3 tentang hasil belajar belajar siswa pada tahap prasiklus dengan materi menulis berita dengan menerapkan model pembelajaran Kooperatif Terpadu Membaca dan Menulis, maka hasil yang diperoleh yaitu: 55\% Kurang, 40\% Cukup, 5\% Baik. Menurut kriteria keberhasilan 55\% Tidak Tuntas, dan 45\% Tuntas.Untuk melihat data ketuntasan belajar siswa, baik secara individual maupun secara klasikal disajikan pada tabel 4.4 berikut. 
Tabel 4.4

Ketuntasan Hasil Belajar Tahap Prasiklus

\begin{tabular}{|r|l|c|}
\hline \multicolumn{1}{|l|}{ No. } & \multicolumn{1}{|c|}{ Ukuran Keberhasilan } & Keterangan \\
\hline 1 & Ketuntasan belajar individu & 9 orang \\
\hline 2 & Ketuntasan belajar klasikal & $45 \%$ \\
\hline & Nilai rata-rata & 68,75 \\
\hline
\end{tabular}

Berdasarkan tabel 4.4 tentang hasil belajar pada tahap prasiklus, pembelajaran Bahasa Indonesia tentang menulis berita ternyata belum tuntas, baik secara individual maupun secara klasikal, karena nilai siswa masih berada di bawah indikator keberhasilan 90\%.Dari tabel di atas dapat diketahui bahwa nilai rata-rata siswa pada tahap prasiklus hanya mencapai 65 saja. Rendahnya keterampilan siswa dalam menulis berita ini disebabkan beberapa faktor internal ataupun eksternal.

Faktor internal yang mempengaruhi kurang berhasilnya penguasaan keterampilan menulis berita pada saat prasiklus yaitu kurangnya pemahaman siswa tentang menulis berita dengan menggunakan Ejaan yang disempurnakan (EYD), dan kepedulian antarkalimat juga masih kurang diperhatikan.Selain faktor internal, faktor eksternal juga berpengaruh. Faktor eksternal itu bisa datang dari guru, kekurangan yang terlihat yaitu kurang jelasnya guru dalam membuat soal ganda, sehingga siswa dalam mengerjakan soal banyak yang tidak mengerti.

\section{b. Hasil Penelitian Siklus I}

\section{1) Pertemuan ke-1}

Siklus I ini merupakan tindakan awal penelitian yang dilakukan setelah mengetahui hasil tes pada tahap prasiklus yang ternyata memerlukan tindak lanjut dan perbaikan atas segala permasalahan yang muncul dalam rangka meningkatkan keterampilan menulis berita. Siklus I ini dilaksanakan pada Rabu, 22 April 2018. Setelah dilaksanakan kegiatan pembelajaran bahasa Indonesia pada pertemuan ke-1 dalam siklus I, diperoleh hasil sebagai berikut.

\section{a) Hasil Belajar Menulis Berita}

Hasil yang diperoleh dari pelaksanaan pembelajaran Bahasa Indonesiatentang menulis berita pada siswa kelas VIII A SMP Negeri 2 Labuan Amas Utara adalah sebagai berikut.

Tabel 4.5

Hasil Belajar Siswa Pertemuan Siklus I Pertemuan ke-1

\begin{tabular}{|l|l|l|c|}
\hline No. & Nama & Nilai & Kriteria Keberhasilan \\
\hline 1 & Abdul Hakim & 80 & Tuntas \\
\hline 2 & Ahmad Jarkasi & 70 & Tidak Tuntas \\
\hline 3 & Ahmad Sayuti & 70 & Tidak Tuntas \\
\hline 4 & Amrullah & 75 & Tuntas \\
\hline 5 & Haris Fadillah & 70 & Tidak Tuntas \\
\hline 6 & Ida Rahma & 70 & Tidak Tuntas \\
\hline
\end{tabular}




\begin{tabular}{|l|l|c|c|}
\hline 7 & Kamarudin & 75 & Tuntas \\
\hline 8 & Karina & 60 & Tidak Tuntas \\
\hline 9 & Khairunnisa & 70 & Tidak Tuntas \\
\hline 10 & Muhammad Eko & 65 & Tidak Tuntas \\
\hline 11 & Muhammad Faisal & 80 & Tuntas \\
\hline 12 & Muhammad Ibnu & 70 & Tidak Tuntas \\
\hline 13 & Muhammad Izuddin & 80 & Tuntas \\
\hline 14 & Muhammad Jaini & 75 & Tuntas \\
\hline 15 & Muhammad Rifani & 70 & Tidak Tuntas \\
\hline 16 & Norlisa & 70 & Tidak Tuntas \\
\hline 17 & Radiah & 65 & Tidak Tuntas \\
\hline 18 & Riska Hidayati & 75 & Tuntas \\
\hline 19 & Sahrani & 75 & Tuntas \\
\hline 20 & Saniyah & 70 & Tidak Tuntas \\
\hline & Jumlah Nilai & 1435 & \\
\hline & Rata-rata & 71,75 & \\
\hline
\end{tabular}

Peningkatan kualitas pembelajaran bahasa Indonesia yaitu materi menulis berita melalui penerapan model pembelajaran Kooperatif Terpadu Membaca dan Menulis dinilai dari hasil kinerja siswa selama melaksanakan prasiklus, siklus I, siklus II. Pada observasi prasiklus hasil kinerja yaitu siswa nilai rata-rata adalah 65 , pada siklus I nilai rata-rata kinerja siswa adalah 74,75 , dilanjutkan pada siklus II nilai rata-rata kinerja siswa adalah 79.

Meningkatnya keaktifan siswa melalui penerapan model pembelajaran Kooperatif Terpadu Membaca dan Menulis ternyata memberikan konstribusi yang luar biasa dalam proses pembelajaranmenulis berita. Hal tersebut dibuktikan dengan adanya peningkatan yang cukup signifikan ketika sebelum dan setelah penerapan model pembelajaran Kooperatif Terpadu Membaca dan Menulis didapatkan hasil bahwa lebih dari $75 \%$ siswa dapat aktif dalam pembelajaran dengan hasil perolehan nilai yang memuaskan.

Hal di atas dapat tercapai dengan baik karena adanya interaksi yang bagus antara guru dan siswa dalam proses pembelajaran. Juga ketepatan strategi pembelajaran menjadi salah satu faktor penting keberhasilan penelitian ini, diharapkan dapat memaksimalkan kemampuan siswa dalam belajar, sehingga apa yang menjadi tujuan bersama dalam proses belajar mengajar dapat tercapai dan memberikan manfaat bagi siswa dan juga guru. Berdasarkan hal tersebut dapat dikatakan bahwa penerapan model pembelajaran Kooperatif Terpadu Membaca dan Menulis terbukti efektif dan tepat digunakan dalam meningkatkan kemampuan siswa dalam menulis berita.

Dari grafik di atas dapat diketahui bahwa hasil belajar dengan penerapan model pembelajaran Kooperatif Terpadu Membaca dan Menulis dapat meningkatkan hasil belajar siswa. Hal ini terlihat pada nilai rata-rata siklus I dan siklus II yang semakin meningkat, nilai rata-rata siklus I pertemuan ke-1, yaitu 71,75 dan pada pertemuan ke-2, yaitu 74,75, sedangkan nilai rata-rata pada siklus II pertemuan ke-1, yaitu 76 dan pada pertemuan ke-2, yaitu 79. 
Dari grafik di atas dapat diketahui bahwa ukuran keberhasilan belajar siswa pada akhir siklus I, yaitu ketuntasan belajar individu sebanyak 12 orang dan ketuntasan belajar klasikal sebanyak 60\%. Sedangkan pada akhir siklus II, ketuntasan belajar individu sebanyak 19 orang dan ketuntasan belajar klasikal sebanyak 95\%. Dengan demikian, dapat dikatakan bahwa hasil belajar siswa dinyatakan tuntas baik secara individu maupun klasikal, karena nilai siswa berada di atas indikator keberhasilan, yaitu $90 \%$.

Dari hasil observasi dalam proses pembelajaran dapat ditarik kesimpulan bahwa model pembelajaran yang dilaksanakan merupakan hal yang baru bagi siswa. Siswa merasa senang mengikuti pembelajaran, lebih mudah memahami materi dan lebih cepat dalam menyelesaikan tugas. Hal ini dapat dilihat dari persentase hasil pembagian angket kepada siswa, yang dimuat pada tabel berikut.

Tabel 4.25

Persentase Angket Respons Siswa

\begin{tabular}{|c|c|c|c|c|c|c|c|}
\hline \multirow[t]{2}{*}{ No. } & \multirow[t]{2}{*}{ Pertanyaan } & \multicolumn{2}{|c|}{ Ya (senang) } & \multicolumn{2}{|c|}{$\begin{array}{l}\text { Tidak (tidak } \\
\text { senang) }\end{array}$} & \multicolumn{2}{|c|}{$\begin{array}{l}\text { Tidak ada } \\
\text { pendapat }\end{array}$} \\
\hline & & $\begin{array}{l}\text { Jumlah } \\
\text { siswa }\end{array}$ & $\%$ & $\begin{array}{l}\text { Jumlah } \\
\text { siswa }\end{array}$ & $\%$ & $\begin{array}{l}\text { Jumlah } \\
\text { siswa }\end{array}$ & $\%$ \\
\hline 1. & $\begin{array}{l}\text { Apakah Anda senang } \\
\text { dalam mengikuti } \\
\text { pembelajaranKooperatif } \\
\text { Terpadu Membaca dan } \\
\text { Menulis? }\end{array}$ & 19 & $95 \%$ & 1 & $5 \%$ & 0 & 0 \\
\hline 2. & $\begin{array}{l}\text { Apakah model } \\
\text { pembelajaran Kooperatif } \\
\text { Terpadu Membaca dan } \\
\text { Menulis dapat menarik } \\
\text { minat Anda terhadap } \\
\text { pembelajaran } \\
\text { menulisberita? }\end{array}$ & 18 & $90 \%$ & 2 & $9 \%$ & 0 & 0 \\
\hline 3. & $\begin{array}{l}\text { Apakah dengan model } \\
\text { pembelajaran Kooperatif } \\
\text { Terpadu Membaca dan } \\
\text { Menulis ini Anda dapat } \\
\text { menguasai } \\
\text { pembelajaran materi } \\
\text { maksimal? }\end{array}$ & 20 & $100 \%$ & 0 & 0 & 0 & 0 \\
\hline 4. & $\begin{array}{l}\text { Apakah materi yang } \\
\text { disampaikan sesuai atau } \\
\text { cocok untuk diberikan } \\
\text { kepada Anda? }\end{array}$ & 19 & $95 \%$ & 1 & $5 \%$ & 0 & 0 \\
\hline 5. & $\begin{array}{l}\text { Menurut Anda, } \\
\text { apakah latihan (soal) yang } \\
\text { berikan Guru kepada Anda } \\
\text { terlalu sulit memberatkan } \\
\text { Anda? }\end{array}$ & 19 & $95 \%$ & 1 & $5 \%$ & 0 & 0 \\
\hline
\end{tabular}

Dari persentase yang ada pada tabel di atas menunjukkan bahwa pembelajaran Bahasa Indonesia di kelas VIII A SMP Negeri 2 Labuan Amas Utara dengan materi menulis berita dengan 
menerapkan model pembelajaran Kooperatif Terpadu Membaca dan Menulis mendapat respons yang positif dari siswa, meskipun model pembelajaran Kooperatif Terpadu Membaca dan Menulis ini masih dianggap hal yang baru bagi para siswa, tetapi dengan adanya inovasi tersebutlah, siswa menjadi bersemangat dalam belajarnya di kelas, serta juga dapat meningkatkan hasil belajar keterampilan menulis berita.

\section{SIMPULAN}

Penerapan pembelajaran Kooperatif Terpadu Membaca dan Menulis dapat meningkatkan hasil belajar siswa SMP Negeri 2 Labuan Amas Utara pada materi keterampilan menulis berita. Hal ini dibuktikan dari kesimpulan berikut ini.

1. Setelah proses pembelajaran pertemuan ke-2 siklus II selesai dilaksanakan dengan materi menulis berita, diketahui hasil belajar siswa menunjukkan peningkatan pada ketuntasan belajar siswa, baik secara individual maupun klasikal. Dari kedua siklus yang telah dilaksanakan guru dan siswa, dapat dilihat peningkatan hasil belajar siswa dengan materi menulis berita dengan penerapan model pembelajaran Kooperatif Terpadu Membaca dan Menulis. Pada tahap prasiklus nilai rata-rata siswa hanya mencapai 65 saja, dengan ketuntasan belajar individu sebanyak 5 orang dan ketuntasan belajar klasikal 25\%. Sedangkan pada akhir siklus I, diperoleh nilai rata-rata siswa 74,75 dengan ketuntasan belajar individu sebanyak 12 orang dan ketuntasan belajar klasikal $60 \%$, ini belum bisa dikatakan berhasil atau tuntas, karena nilai siswa masih berada di bawah indikator keberhasilan 90\%. Setelah siklus II selesai dilaksanakan, maka terlihat peningkatan hasil belajar siswa sebesar 35\% dengan nilai rata-rata siswa di atas indikator keberhasilan yaitu 75, dengan ketuntasan belajar individu sebanyak 19 orang dan ketuntasan belajar klasikal $95 \%$ dan dinyatakan tuntas.

2. Berdasarkan data observasi, dapat disimpulkan bahwa tahapan-tahapan pembelajaran berlangsung efektif, karena tidak ada lagi kegiatan yang belum terlaksana dari prosesbelajarmengajar yang berjalan lancar dan mendapat respons yang baik dari siswa. Hal ini dapat dibuktikan dari keaktifan siswa dalam mengikuti proses pembelajaran.

3. Pembelajaran Bahasa Indonesia di kelas VIII A SMP Negeri 2 Labuan Amas Utara dengan materi menulis berita dengan menerapkan model pembelajaran Kooperatif Terpadu Membaca dan Menulis mendapat respons yang positif dari siswa, meskipun model pembelajaran Kooperatif Terpadu Membaca dan Menulis ini masih dianggap hal yang baru bagi para siswa, tetapi dengan adanya inovasi tersebutlah, siswa menjadi bersemangat dalam belajarnya di kelas, serta juga dapat meningkatkan hasil belajar keterampilan menulis berita. 


\section{SARAN}

Berdasarkan simpulan di atas, peneliti berusaha mengemukakan beberapa saran-saran atau masukan dalam pengajaran menulis di kelas VIII A SMP Negeri 2 Labuan Amas Utara Kabupaten Hulu Sungai Tengah, antara lain:

1. Diharapkan agar guru Bidang Studi Bahasa dan Sastra Indonesia dapat melaksanakan Penelitian Tindakan Kelas, agar kekurangan-kekurangan yang didapat dalam proses pembelajaran dapat diperbaiki, sehingga proses pembelajaran dapat berjalan lancar. Selain itu, guru hendaknya juga mampu menggunakan metode atau model pembelajaran dengan tepat, agar tujuan yang diinginkan bisa tercapai.

2. Para siswa hendaknya terus berlatih dan selalu berusaha untuk meningkatkan kemampuan menulis, khususnya menulis berita, agar nantinya konsentrasi dan daya fokus mereka bisa lebih baik dalam menerima pelajaran yang disampaikan oleh guru.

\section{DAFTAR RUJUKAN}

Abbas, Ersis Warmansyah. 2007. Menulis Mari Menulis. Jakarta: Mata Khatulistiwa.

Arikunto, dkk. 2012. Penelitian Tindakan Kelas. Yogyakarta: Aditya Media.

Depdiknas. 2006. Kurikulum Tingkat Satuan Pendidikan (KTSP) Sekolah Menengah Pertama. Banjarmasin: Dinas Pendidikan Prov. Kalsel. Subdin Bina Diknas.

Chaer, Abdul. 2010. Bahasa Jurnalistik. Jakarta: Rineka Cipta Aksara.

E. Slavin, Robert. 2015. Cooperative Learning Teori, Riset dan Praktik. Bandung: Penerbit Nusa Media.

Faidi, Ahmad. 2013.Tutorial Mengajar untuk Melejitkan Otak Kanan dan Kiri Anak. Yogyakarta: DIVA Press.

Hernacki, Mike dan Bobbi De Potter. 2005. Quantum Learning MembiasakanBelajar Nyaman dan Menyenangkan. Bandung: Kaifa.

Restuti dan E. Kosasih. 2009. Mandiri Mengasah Kemampuan Diri Berbahasa Indonesia. Jakarta: Erlangga.

Semi, M. Atar. 2007. Dasar-Dasar Keterampilan Menulis. Bandung: Angkasa. 